\title{
A Study of Mental Health among Secondary Students of Kashmir
}

\author{
Amees Tuhasaif Aezum and Dr. V.K. Sharma \\ 1. Research Scholar, Glocal School of Education, Glocal University, Saharanpur, UP, India \\ 2. Professor, Glocal School of Education, Glocal University, Saharanpur, UP, India
}

\begin{abstract}
The present study is a modest effort to compare private and govt. secondary school on various components of Mental Health. Translated English version of Mental Health Battery from Hindi version by A.K Singh and Alpana Sen Gupta consisting of six dimensions (130 items) were administered to measure the mental health status. No significant difference was found between private and govt. students on general intelligence. The mean difference favoured private students but the difference failed to arrive at any level of confidence. It has been found that both the private and govt. students displayed somewhat similar intelligence. It has been found that private and govt. students differ significantly on overall dimensions of mental health battery. The private students were found to have better mental health than government students.
\end{abstract}

Keywords: Mental health, Academic Achievement, Secondary School Students, Kashmir

\section{INTRODUCTION}

Mental health generally indicates optimal ability to maintain relationships with individuals and groups in accordance with existing cultural patterns. We have become conscious of the importance of bodily health but only a small number of people realize that the health of mind is as important as that of the body. Many people live unhappy lives on account of mental disorders. An average man does not know that there are laws of mental health as there are laws of bodily health, so he goes on bearing his mental ills in a spirit of resignation. If the body is not properly exercised and scientifically fed, it deteriorates. Discomfort and unhappiness are the natural consequences of the neglect of the body. But, 'even a perfectly developed body is useless, unless it is directed by a well-balanced and capable mind'. In the stress of modern civilization, lack of mental health may mean unhappiness, failure, misery and even insanity in a large number of cases. Aware of the need for more research, training and services in the field of mental health, Congress in 1946 passed its first comprehensive mental health bill, the National Mental Health Act, which laid the basis for the federal Government's present mental health programme. The 1946 bill provided for the establishment of National Institute of Mental Health (NIMH) in or near Washington D.C. to serve as a central research and training centre and headquarters for the administration of a grant-in-aid programme. Ours is the age of tremendous growth of knowledge and rapid social change. Modern science and technology effects all phases of our life. 
Adolescence is the most volatile stage in the development of personality. In western nations, adolescence has traditionally been viewed as a period of 'storm and stress', a dramatic upheaval of emotions and behavior. Mental, physical and every other kind of development takes place at a rapid pace during this stage. Young boys and girls manifest signs of approaching adulthood. This physical development is accompanied by mental development due to which they do not appreciate being treated as children. Imagination and emotionality are at their highest pitch while the adolescent is passing through this period. It mostly happens that many adolescents cannot clarify their difficulties and problems so that they require guidance from their parents, teachers and psychologists. It is for the guide to understand the adolescent and to sympathize with him/her and to offer him/her affection or advice. Scolding or punishing them is not very efficacious. They should be given the opportunity of expressing their desires and mental tendencies. So, the importance of mental health cannot be overestimated. Fortunately, a great deal of attention has been given to this important aspect of the individual's total personality. Not only has the school become much more conscious of its responsibility in this connection, but the community at large has also demonstrated its interest in the problem through very active mental health groups composed of lay persons as well as professional, medical, clinical and teaching personnel.

In fact, the foremost concern of education, today, is to produce mentally healthy persons and thereby well-adjusted personalities because mentally healthy persons are the real assets of the society of the 21st century. During adolescence, autonomy becomes an important issue for the first time since toddlerhood. According to Laurence Steinberg and Susan Silverberg (1986), youngsters are working on three major aspects of autonomy: emotional autonomy, resistance to peer pressure and self reliance.

When something shocking happens, attention is immediately focused on the need for doing something about mental health in our schools. Thus for the development of the society in the scientific competitions age, it is the teacher who can teach mental hygiene to the children especially adolescents in the class which in turn can maintain balanced mental health. Thus the mental health of teachers and adolescents are the most important topics of the day because if teachers have mental health problems, they will most certainly affect their students in negative and even in dangerous ways. Therefore, it is essential to give emphasis on mental health of both educator and the educant in the educational institution.

Kashmir is unique not only geographically but also in its history, culture and ethnicity. It is one of the most beautiful and fertile valleys in the world. Kalhana, in his Raj Tarangni has said about the valley of Kashmir, "It is the country where the sun shines mildly, being place created by Kashyapa as if for his glory. Learning, lofty houses, the saffron, iced water and grapes are common here.

The population of Kashmir is predominantly Muslim and more related to Central Asia than to India in both appearance and temperament. Despite its Muslim majority, Kashmir has a strong Hindu minority. Kashmiris are broad shouldered and usually of medium to tall stature. They have a well developed forehead, a long narrow face and a predominant straight and finely cut nose. They are talkative, cheerful and humorous. Most of the Kashmiris live in the villages and are dependent on agriculture. Paddy, orchards, saffron and dry fruits are the main crops grown by them while the urban Kashmiris are engaged in business, tourism, hotel management, carpet making, wood carving, paper mashie and several other handicrafts. 
On the basis of review of related literature, studies on mental health and academic achievement have been taken in some districts of Jammu \& Kashmir state by many researchers and educationists but no such study has been taken in district Anantnag. Therefore, the investigator feels it important to conduct a research on mental health and academic achievement of Higher Secondary students in district Anantnag. The present study will become the guidance for policy planners and academicians to come to the expectations of the adolescents especially of those studying in Higher Secondary schools so that they will have a better mental health and academic achievement.

\section{OBJECTIVES:}

The following objectives were formulated for the present study:

1. To study the mental health private and govt. secondary school students of District Anantnag.

2. To compare Private and Govt. secondary school students on mental health battery.

\section{HYPOTHESES}

The following hypotheses were formulated for the present study.

1. There is no significant difference between Private and Govt. secondary school students on mental health battery.

\section{OPERATIONAL DEFINITIONS OF TERMS AND VARIABLES}

1. Mental Health: Mental Health of Science and Soc. Science secondary students for the present study refer to the scores obtained by the subjects on A.K. Singh and Alpana Sen Gupta's, "Mental Health Battery".

2. Academic Achievement: Academic achievement of private and govt. secondary students refers to the knowledge attained and skills developed in the school subjects. So academic achievement means the achievement of students in academic subjects. For this purpose, the aggregate Marks obtained by the subjects in previous two exams served as measures of academic achievement.

\section{SAMPLE}

The sample for the present study consisted of 200 secondary school students (100 Private and 100 Government) selected randomly from the different schools of District Anantnag.

\section{TOOLS}

Following tools were used for the present study:-

Tools I: - Mental Health Battery by A.K Singh and Sen Gupta (original Hindi version translated by Mrs. Gulnaz in English version).

The following six popular indices of mental health have finally been selected for inclusion in the present battery.

1. Emotional stability

2. Over-all adjustment

3. Autonomy 

4. Security insecurity
5. Self concept
6. Intelligence

A brief description of each of these indices is as under:-

1. Emotional Stability: - It refers to experiencing subjective stable feelings which have positive or negative values for the individuals.

2. Adjustment:- It refers to individuals achieving an overall harmonious balance between the demands of various aspects of environment such as home, health, social, emotional and social on the one hand and cognition on the other hand.

3. Autonomy: - It refers to a stage of independence and self determination in thinking. Security Insecurity: - It refers to a high or low senses of safety, confidence, freedom from fear, apprehension or anxiety particularly with respect to fulfilling the persons present of future needs.

5. Self-concept: - It refers to the sum total of the persons attitudes and knowledge towards himself and evaluation of his achievements.

6. Intelligence: - It refers to general mental ability which helps the person in thinking rationally, and in behaving purposefully in his environment.

Table 1: Showing the mean comparison of Private and Govt. Secondary students on emotional stability of mental health battery

\begin{tabular}{|c|c|c|c|c|}
\hline Category & Mean & S.D & t-value & Level of significance \\
\hline private students & 10.25 & 3.25 & 5.00 & Significant at 0.01 level \\
\cline { 1 - 2 } government students & 8.35 & 2.12 & & \\
\hline
\end{tabular}

The perusal of above table shows the mean comparison of private and govt. secondary students on emotional stability of mental health battery. The above table reveals that the mean score of private students is higher than the mean score of private students and the difference is significant at 0.01 level. The private students display better emotional stability as compared to governemnt students.

Table 2: Showing the mean comparison of Private and Govt. Secondary students on over all adjustment of mental health battery.

\begin{tabular}{|c|c|c|c|c|}
\hline Category & Mean & S.D & t-value & Level of significance \\
\hline private students & 36.25 & 3.25 & \multirow[b]{2}{*}{7.36} & \multirow[b]{2}{*}{ Significant at .01 level } \\
\hline government students & 32.20 & 4.48 & & \\
\hline
\end{tabular}

A quick look on the above table reveals that there is a significant mean difference between two groups of students on overall adjustment of mental health battery. The mean score favours private students which indicates that private students showed better overall adjustment than the government students. 
Table 3: Showing the mean comparison of Private and Govt. Secondary students on autonomy of mental health battery.

\begin{tabular}{|l|l|l|l|l|}
\hline Category & Mean & S.D & t-value & Level of significance \\
\hline private students & 13.28 & 2.40 & \multirow{2}{*}{6.42} & Significant at .01 level \\
\cline { 1 - 3 } government students & 10.71 & 3.21 & & \\
\hline
\end{tabular}

The perusal of above table shows that the two groups of students viz. Private and Govt. secondary students differ significantly on autonomy component of mental health battery and the difference is significant at 0.01 level. The result reveals that private students are more autonomous and have better independence and self determination in thinking than government students.

Table 4: Showing the mean comparison of Private and Govt. secondary students on security-in security of mental health battery.

\begin{tabular}{|l|l|l|l|l|}
\hline Category & Mean & S.D & t-value & Level of significance \\
\hline private students & 14.27 & 3.12 & \multirow{2}{*}{5.37} & Significant at .01 level \\
\cline { 1 - 3 } government students & 12.28 & 2.12 & & \\
\hline
\end{tabular}

A quick look on the above table reveals that there is a significant mean difference between the two groups of students on security-insecurity component of mental health battery and difference was found to be significant at 0.01 level. The mean score favours private students which indicates that private students showed better sense of safety, confidence, freedom from fear than the government students.

Table 5: Showing the mean comparison of Private and Govt. secondary students on Self-concept of mental health battery.

\begin{tabular}{|l|l|l|l|l|}
\hline Category & Mean & S.D & t-value & Level of significance \\
\hline private students & 14.12 & 3.40 & 5.66 & Significant at .01 level \\
\cline { 1 - 3 } government students & 13.10 & 2.58 & & \\
\hline
\end{tabular}

The perusal of above table shows the mean comparison of Private and Govt. secondary students on self concept dimension of mental health battery. As the mean score favours private students which indicates that private students showed better attitude, knowledge of themselves and evaluation of their achievements than the government students. 
Table 6: Showing the mean comparison of Private and Govt. secondary students on general intelligence of mental health battery.

\begin{tabular}{|l|l|l|l|l|}
\hline Category & Mean & S.D & t-value & Level of significance \\
\hline private students & 28.13 & 4.97 & \multirow{2}{*}{1.56} & Significant at .01 level \\
\cline { 1 - 3 } government students & 27.10 & 4.36 & & \\
\hline
\end{tabular}

The perusal of above table reveals that there is no significant mean difference between Private and Govt. students on general intelligence. The table indicates that both the groups displayed somewhat similar intelligence quotient.

Table 7: Showing the mean comparison of Private and Govt. secondary students on overall score of mental health battery.

\begin{tabular}{|l|l|l|l|l|}
\hline Category & Mean & S.D & t-value & Level of significance \\
\cline { 1 - 3 } private students & 59.72 & 5.12 & & \\
\cline { 1 - 3 } & 55.12 & 6.42 & & Significant at 0.01 level \\
\hline
\end{tabular}

The perusal of above table shows the mean difference of Private and Govt. students on overall dimensions of mental health battery. The above table reveals that there is significant mean difference between Private and Govt.students on overall dimension of mental health and the difference is significant at 0.01 level. As the mean score favours private students which indicates that private students displayed better mental health than government students.

\section{CONCLUSIONS}

The following are some of the conclusions drawn from the present study.

a) It has been found that private and govt. students differ significantly on emotional stability of mental health battery. The private students were found to be more emotionally stable than the government students.

b) It has been found that private and govt. students differ significantly on over all adjustment of mental health battery. The private students were found to have better overall adjustment than government students.

c) It has been found that private and govt. students differ significantly on autonomy dimension of mental health battery. The private students were found to be more autonomous and self confident than the government students.

d) It has been found that private and govt. students differ significantly on security-in security dimension of mental health battery. The private students were found to have high sense of security 
than the government students.

e) It has been found that private and govt. students differ significantly on self-concept dimension of mental health battery. The private students were found to have better attitude and knowledge about themselves than the government students.

f) No significant difference was found between private and govt. students on general intelligence. The mean difference favoured private students but the difference failed to arrive at any level of confidence. It has been found that both the private and govt. students displayed somewhat similar intelligence.

g) It has been found that private and govt. students differ significantly on overall dimensions of mental health battery. The private students were found to have better mental health than government students.

h) The perusal of above table shows the mean difference of private and govt. students on overall dimensions of mental health battery. The above table reveals that there is significant mean difference between private and govt. students on overall dimension of mental health and the difference is significant at 0.01 level. As the mean score favours private students which indicates that private students displayed better mental health than government students.

\section{REFERENCES}

Alberta E. Pruitt, (2002). How the Physically Handicapped Learn to Read. Reading Teacher vol. 7. pp. 131-137. published by International Reading Association. stable Ann Llewellyn and Man Cheung Chung, (2005). Self Esteem of Children With Physically Disabilities Problems and Dilemmas of Research. Journal of Development of Physical Disabilities. Published by Division of Psychology, Health Sciences, University of Wolver Hampton WVI, IDJ England.

Archana, K. P., (2002). Correlates of Academic Achievement Indian Journal of Educational Research Vol. 21 pp. 75-76.

Aurn, K. S. \& chandha, N. K. (1988). Research in Psychological Issues. Published by New Delhi Eurasia Publishing House.

Best J.W (1983) Research and Education. New Delhi. Published by Prentice Hall of India Pvt. Ltd.

Borg, W. R \& Call, M.D. (1979) Educational Research- an Introduction: New York. Published by Longman pp. 444-449

Borg, W.R \& Gall, M.D (1976) Educational Research an Introduction .New York Longman Publishers.

Buch, M.B. (1974) A Survey of Research in Education Center for Advanced Studies in Education.

Chatrwrjee, R. (1985) Self-Concept and Blind Children, cited in Journal of Indian Education vol. 2 , No. 5.

Chawala Preeti, (2008). Personal Adjustment of physically Disabled and Normal students at senior secondary students. Published by Journal of the Indian Academy of Applied psychology, Vol. 32. pp. 43-46 
D. F. Elisions Nash, (2002). Case Study of Physically Handicapped Students. The British Medical Journal vol. 2. No. 511 .p.p. 1534 published by BMJ publishing group stable

Donnal, M. Pappenfort and Dee Morgan Kilpatrick, (2002). Opportunity for Physically Handicapped Children, a Study of Attitudes and Practice in Settlements and Community Centers. The Social Service Review vol. 41. p.p. 179-188 published by the University of Chicago press. Stable URL: http://wwwjstro. or\% stable/30020396.

Dr. L. Govinda Rao, (2007). Perspectives on special education. Published by Neelkamal Publication Pvt. Ltd. Sultan Bazar Hyderabad.

Dr. R.A. Sharma, (2008). Fundamentals of Special Education. Published by Vinay Rakheja Meentit. pp. 149,194, 212.

E.P. Quibell, (2000). The Physically Handicapped Child, Functional Assessment of the Disability as an aid to Planning. The British Medical Journal vol. 2. No. 4999 pp. 991-993 published by BMJ publishing group stable.

Ed cairns and Christopher Alan Lewis (2000). Collective Memories, Political Violence and Mental Health in Northern Ireland, published by American Journal of Psychology vol. 1.

Faria, Farhat. (2001). Managing Mentally and Physically Challenged Students. Published by Journal of National Medical Association Vol. 101.No.12

Frank, M. G. \& Deniel Resely. (1986). Sociometric Difference Between Mildly Handicapped and non Handicapped Black and While Students. Cited in Journal of Educational Psychology, vol. 79. No 2.

Good C. V. (1963). Introduction to Educational Research. Published by New York Appleton Century Craft.

Gulnaz. (2004). A Study of Mental Health and Academic Achievement of adolescent boys and girls. Unpublished M.phil dissertation university of Kashmir.

Harry, J. Baker, (2000). A Study of Physically and Mentally Exceptional Children. Review of Educational Research vol. 6 pp. 514- 523 published by American Educational Research Association.

Headfield, T. K. (2003). Mental Health. In Benjamin B. Lahey (Ed) Psychology an Introduction ( $6^{\text {th }}$ edition) published by Tata McGraw-Hill'NewDelhi, p. 326.

Hussain Akbar, (2007). Self Concept of Physically Challenged Students. Published by Journal of the Indian Academy of Applied psychology Vol. 32. pp. 43-46

INEKE.M Pit.Ten.Cate, (2001). Disability and Rehabilitation. University of Southampton, Center for Research and Psychological Development, Dept. of Psychology. Published by International Journal of Psychology, Vol. 2. No. 9. pp. 399-408

James, E. Yesseldyke. Bob Algozzine, (2006). Special Education a Practical Approach for Teacher. Published by Kanishka publication, New Delhi

Janardan Prasad, (2007). Education of the Handicapped Children. Published by Kanishka Publication, New Delhi

Jasic Spataro and Paul, E. Mullen, (2004). Impact of Child Sexual Abuse on Mental Health, published by Researched Based Journal of Education vol. 4.

John Sutton, (2004) Mental Health. In Sharma and Sharma (Ed.), Advanced Applied Psychology Vol. 1st pp. 366-67, New Delhi: Atlantic Publishers 
John, N. Walton, (2000). The General Care of the Physically Challenged. The British Medical Journal vol. 2. No. 5437.p.p.1296 published by BMJ publishing group stable URL http://www.jstro. org/stable/25404610.

Karmani Mohammad, (2007). Comparing Self-Esteem and Self-Concept of Physically Challenged and Normal students. Procedia-social and Behavioral science published by Elsevier Ltd. Vol. 2. pp. 46-49.

Kelsey, B. and Wheelor, V. (2001). Family Perception of Mental Health Isssues, Among College Students Development.

Kerlinger, Fred, N. (1973) Foundation of Behavioral Research. New York, Holt, Rinehart and Winslom publications.

Kilenger, P. N. (1983) Foundations of Behavioral Research. New Delhi. Surjeet Publication.

Kobel Darja \& Musek Janek, (2001). A study of Self Concepts and Academic Achievement. British Journal of Psychology Vol. 3rd pp. 44.47 